\title{
Celiac Disease Presenting with Vitamin D Deficiency and Low Bone Mineral Density in the Puerperium
}

\author{
Lohusalık Döneminde D Vitamin Eksikliği ve Düşük Kemik Mineral Yoğunluğu ile \\ Ortaya Çıkan Çölyak Hastalığ̣
}

\author{
Mustafa ÜNÜBOL, ${ }^{1}$ Engin GÜNEY, ${ }^{1}$ Volkan YAZAK, ${ }^{2}$ Umut ÇAKIROĞLU, ${ }^{2}$ Adil COŞKUN, ${ }^{3}$ İbrahim METEOĞLU ${ }^{4}$ \\ ${ }^{1}$ Department of Internal Medicine, Medical Faculty of Adnan Menderes University, \\ Division of Endocrinology and Metabolic Diseases, Aydin, Turkey \\ ${ }^{2}$ Department of Internal Medicine, Medical Faculty of Adnan Menderes University, Aydin, Turkey \\ ${ }^{3}$ Department of Gastroenterology, Medical Faculty of Adnan Menderes University, Aydin, Turkey \\ ${ }^{4}$ Department of Pathology, Medical Faculty of Adnan Menderes University, Aydın, Turkey
}

\begin{abstract}
Celiac disease (CD) is an autoimmune disease triggered by the ingestion of foods containing gluten (gliadin). Celiac disease is usually diagnosed in childhood. Celiac disease, which has an insidious onset in adults, is rarely seen in the puerperium. A 26-year-old female admitted with the complaints of cramps in her hands and feet, and weight loss in the puerperium. Vitamin D deficiency was found with concomitant hypocalcemia and low bone mineral density. The patient was diagnosed with $C D$ in the puerperium by means of biopsy and antibody testing. From the first week of the gluten-free diet and supportive therapy, remarkable improvement was observed in the patient's clinical manifestations. In conclusion, although $\mathrm{CD}$ is a disease frequently diagnosed during childhood, it should not be overlooked for the maternofetal health that $C D$ may also develop during pregnancy and the puerperium.
\end{abstract}

Key words: Celiac disease; low bone mineral density; puerperium; vitamin $\mathrm{D}$ deficiency.

Celiac disease (CD) is an autoimmune disorder triggered by the ingestion of foods that contain gluten (gliadin). ${ }^{[1,2]}$ The prevalence of CD ranges from $0.5-1 \%{ }^{[3]}$ The prevalence of undiagnosed CD in the puerperium among women is unknown;
Çölyak hastalığı $(\mathrm{ÇH})$, gluten içeren gıdaların (gliadin) alımıyla tetiklenen otoimmün bir hastalıktır. Çölyak hastalığı tanısı, genellikle çocukluk döneminde konulmaktadır. Erişkinlerde sinsi başlangıçlı olan $\mathrm{ÇH}$, lohusalık döneminde nadir olarak görülmektedir. Yirmi altı yaşında kadın hasta, ellerde ve ayaklarda kramp ve lohusalık döneminde kilo kaybı yakınmasıyla başvurdu. Hipokalsemi ve düşük kemik mineral yoğunluğu ile birlikte olguda D vitamini eksikliği saptandı. Antikor testi ve biyopsi aracılığı ile hastaya, lohusalık döneminde $\mathrm{C} H$ tanısı kondu. Glutensiz diyet ve destekleyici tedavi ile 1. haftadan itibaren hastanın klinik bulgularında belirgin iyileşme gözlendi. Sonuç olarak, ÇH sık olarak çocukluk döneminde tanı konulan bir hastalık olsa da, maternofetal sağlık açısından gebelik ve lohusalık döneminde ortaya çıkabileceği göz ardı edilmemelidir.

Anahtar sözcükler: Çölyak hastalığı; düşük kemik mineral yoğunluğu; lohusalık dönemi; vitamin D eksikliği.

however, CD rarely develops during the first pregnancy or puerperium. ${ }^{[4]}$ Herein, a patient diagnosed with CD who developed vitamin D deficiency and weight loss during the puerperium is presented. 


\section{CASE REPORT}

A 26-year-old primipara presented with complaints of cramps in her hands and feet which began one month after the birth of a $1800 \mathrm{~g}$ low-birth-weight infant at 30 weeks gestation. She had had these symptoms for one month. The physical examination of the patient, who had lost more than $10 \%$ of her body weight $(6 \mathrm{~kg})$ in one month, revealed a positive Chvostek's sign and a negative Trousseau's sign. The results of the laboratory examination were as follows: serum calcium $6.8 \mathrm{mg} / \mathrm{dL}(8.2-10.5 \mathrm{mg} / \mathrm{dL})$; phosphorus $4 \mathrm{mg} / \mathrm{dL}$ (2.5-4.8 mg/dL); albumin $3.6 \mathrm{~g} / \mathrm{dL}$ (3.5-5.2 g/dL); parathormone (PTH) $144.7 \mathrm{pg} / \mathrm{mL}$ (15$65 \mathrm{pg} / \mathrm{mL}) ; 25$-hydroxy vitamin D 25(OH)D $9 \mathrm{ng} / \mathrm{mL}$ $(<10 \mathrm{ng} / \mathrm{ml}$ indicates severe deficiency); potassium $3.5 \mathrm{mEq} / \mathrm{L}(3.5-5.5 \mathrm{mEq} / \mathrm{L})$; hemoglobin $11.8 \mathrm{~g} / \mathrm{dL}$; hematocrit $37.5 \%$; ferritin $20.92 \mathrm{ng} / \mathrm{mL}(5-148 \mathrm{ng} / \mathrm{mL})$; and vitamin B12 $193 \mathrm{pg} / \mathrm{mL}$ (193-982 pg/mL). The levels of blood urea nitrogen (BUN), serum creatinine, thyroid-stimulating hormone, aspartate transaminase, alanine transaminase, alkaline phosphatase, creatine kinase (CK), amylase, and bilirubin along with the leukocyte count were normal. The total $\mathrm{T}$ and $\mathrm{Z}$ scores of the vertebrae by dual energy X-ray absorptiometry were -2.9 and -2.8 , respectively, and the total $\mathrm{T}$ and $\mathrm{Z}$ scores of the femur were both -3.4. The patient declined a bone biopsy planned for the diagnosis of suspected osteomalacia. The anti-endomysium (1/100 titer) and anti-gliadin (1/100 titer) immunoglobulin A (IgA) antibodies were positive. Endoscopically, there was a granular and nodular appearance in the second part of the duodenum and bulbous. Biopsies obtained from the duodenum revealed a loss of villi, the presence of massive intraepithelial lymphocytes, and lymphoplasmacytic infiltration, including eosinophils in the lamina propria. Immunohistochemically, the intraepithelial lymphocytes stained positively for cluster of differentiation (CD) 3 and CD8 but negatively for CD4 and CD20. According to the modified Marsh classification, ${ }^{[5]}$ the results were consistent with $\mathrm{CD}$, type 3B (Figure 1). A gluten-free diet was initiated, and oral calcium and vitamin $\mathrm{D}$ were administered to the patient. The complaints of cramps in her hands and feet resolved after the first week of the gluten-free diet. The calcium and PTH levels of the patient, who gained
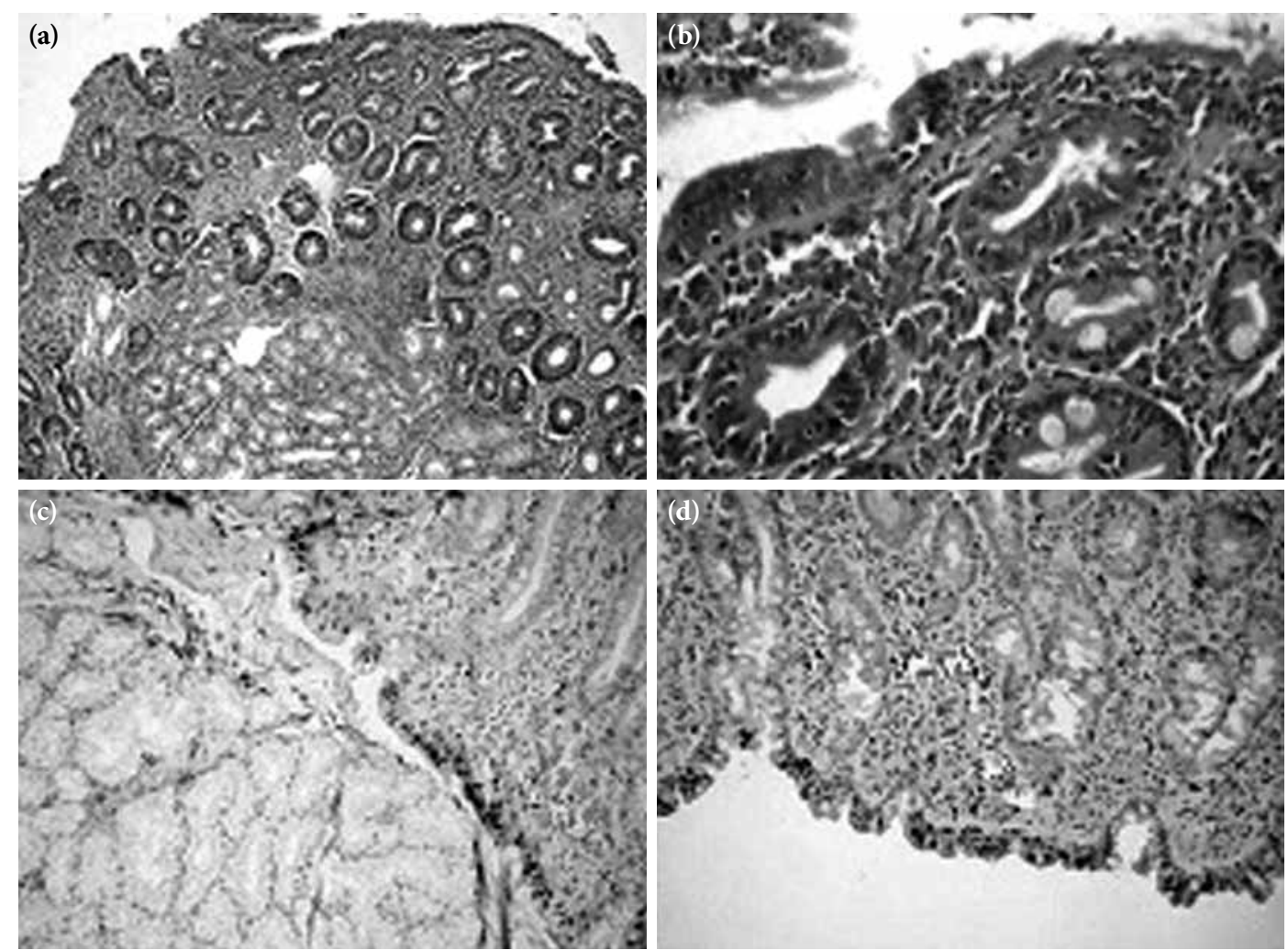

Figure 1. (a) Revealed loss of villi with crypt hyperplasia in the second part of the duodenum (H-E x 100);

(b) Presence of massive intraepithelial lymphocytes and lymphoplasmacytic infiltration, including eosinophils in the lamina propria (H-E x 400), with immunohistochemical staining of the intraepithelial lymphocytes; (c) Positivity for CD3; (d) Positivity for CD8. CD: Cluster of differentiation. 
$5 \mathrm{~kg}$ in the second month of therapy, are now within normal ranges, and she is undergoing follow-up care.

\section{DISCUSSION}

The patient described herein was diagnosed with vitamin $\mathrm{D}$ deficiency and $\mathrm{CD}$ in the puerperium by means of a biopsy and antibody testing.

The causes of hypocalcemia can be differentiated by whether the serum PTH levels are low (hypoparathyroidism) or high (secondary hyperparathyroidism). Secondary hyperparathyroidism is seen in nutritional vitamin $\mathrm{D}$ deficiency, renal insufficiency, vitamin $\mathrm{D}$ resistance, including receptor defects, PTH resistance syndromes, drugs (calcium chelators, bisphosphonates, plicamycin, phenytoin, and ketoconazole), acute pancreatitis, acute rhabdomyolysis, and hungry bone syndrome after parathyroidectomies. $^{[6]}$ Our patient had no history of neck surgery or drug use. Acute pancreatitis, rhabdomyolysis, and renal insufficiency were excluded by physical examination and laboratory evaluations.

In vitamin $\mathrm{D}$ deficiency, osteomalacia, an increase in bone remodeling, and a decrease in bone mineral density (BMD), particularly in the proximal femur, along with an increased risk of osteoporotic fractures, hypocalcemia, hypophosphatemia, and low excretion of urinary calcium may occur. An increase in PTH is also possible for adults. Measuring the $25(\mathrm{OH}) \mathrm{D}$ is necessary for the early diagnosis of vitamin D deficiency ${ }^{[7,8]}$ Low or low-to-normal levels of $25(\mathrm{OH}) \mathrm{D}$ indicate a vitamin $\mathrm{D}$ deficiency due to lack of sunlight, inadequate vitamin $\mathrm{D}$ intake, or intestinal malabsorption. ${ }^{[7]}$ Celiac disease that leads to malabsorption is one of the known causes of vitamin D deficiency. ${ }^{[1]}$ The diagnosis of CD is usually made in childhood. Celiac disease has a more insidious onset in adults. ${ }^{[3]}$ In adults, CD may be expressed with different clinical symptoms. ${ }^{[1,2]}$ In recent years, there has been an increased recognition of possible changes in male and female fertility in CD as well as the potential for adverse outcomes in pregnancy and the post-partum period that may lead to miscarriages and premature low-birth-weight fetal deliveries. ${ }^{[9]}$ In a study conducted by Ciacci et al., ${ }^{[10]}$ the prevalence of recurrent abortion and intrauterine growth retardation (IUGR) in patients with CD was reported to be 8.9 times higher than in the normal population. Reduced birth weight and IUGR have also been recorded in several other studies from European centers. ${ }^{[4,11]}$ Undiagnosed maternal CD appeared to be a far greater risk factor than diagnosed $\mathrm{CD}$, but in a subsequent report, undiagnosed $\mathrm{CD}$ was not associated with an unfavorable outcome of pregnancy. ${ }^{[12,13]}$ Our patient is the mother of a lowbirth-weigth infant. Although rare, CD cases with an onset during pregnancy and the puerperium have been reported. ${ }^{[14-17]}$ Mechanisms involved in the impairment of pregnancy outcome in $\mathrm{CD}$ have been explored to a limited degree. The placentas in mothers affected with CD appear to be abnormal. ${ }^{[9]}$ The reason for the development of $\mathrm{CD}$ in the puerperium is not completely clear, and the exact cause of probable autoimmune activation related to pregnancy or puerperium is not known ${ }^{[18]}$ Rheumatoid arthritis usually enters remission during pregnancy and is exacerbated in approximately $70 \%$ of patients in the post-partum period. Conversely, systemic lupus erythematosus (SLE) has classically been thought to show an exacerbation of the disease in the last trimester of pregnancy. It is believed that humoral immunity is dominant in SLE, and cellular immunity is dominant in RA. ${ }^{[19]}$ The activation of CD during the puerperium has been hypothesized to be related to immunological factors, hormonal factors, or both. ${ }^{[15]}$ The current hypothesis is that the latent $\mathrm{CD}$ cases are stimulated by extreme differences in female hormone levels, particularly by prolactin levels. ${ }^{[18]}$ The sex hormones have remarkable effects on the immune system. Estrogens inhibit T suppressor cells and enhance the antibody production of $\mathrm{B}$ cells. ${ }^{[20]}$ Occasionally, the presentation may be acute, leading to speculation that the activation of $\mathrm{CD}$ may result from maternal exposure to fetal antigens. ${ }^{[16]}$ In conclusion, although $\mathrm{CD}$ is a disease frequently diagnosed during childhood, the possibility that $\mathrm{CD}$ may also develop during pregnancy and the puerperium should not be overlooked.

\section{Declaration of conflicting interests}

The authors declared no conflicts of interest with respect to the authorship and/or publication of this article.

\section{Funding}

The authors received no financial support for the research and/or authorship of this article.

\section{REFERENCES}

1. Green PH, Cellier C. Celiac disease. N Engl J Med 2007;357:1731-43.

2. Clemens PC. Coeliac disease in adults with atypical symptoms. Lancet 1996;347:1050.

3. NIH Consensus Development Conference on Celiac Disease. NIH Consens State Sci Statements 2004;21:1-23.

4. Martinelli P, Troncone R, Paparo F, Torre P, Trapanese E, Fasano C, et al. Coeliac disease and unfavourable outcome of pregnancy. Gut 2000;46:332-5. 
5. Marsh MN. Gluten, major histocompatibility complex, and the small intestine. A molecular and immunobiologic approach to the spectrum of gluten sensitivity ('celiac sprue'). Gastroenterology 1992;102:330-54.

6. Potts JT. Diseases of the parathyroid gland and other hyper- and hypocalcemic disorders. In: Kasper DL, Fauci AS, Longo DL, Braunwald E, Hauser SL, Jameson JL, editors. Harrison's principles of internal medicine. 16th ed. New York: McGraw-Hill; 2005. p. 2259-68.

7. Bringhurst FR, Demay MB, Krane SM, Kronenberg HM. Bone and mineral metabolism in healt and disease. In: Kasper DL, Fauci AS, Longo DL, Braunwald E, Hauser SL, Jameson JL, editors. Harrison's principles of internal medicine. 16th ed. New York: McGraw-Hill; 2005. p. 2246-9.

8. Schubert L, DeLuca HF. Hypophosphatemia is responsible for skeletal muscle weakness of vitamin D deficiency. Arch Biochem Biophys 2010;500:157-61.

9. Freeman HJ. Reproductive changes associated with celiac disease. World J Gastroenterol 2010;16:5810-4.

10. Ciacci C, Cirillo M, Auriemma G, Di Dato G, Sabbatini F, Mazzacca G. Celiac disease and pregnancy outcome. Am J Gastroenterol 1996;91:718-22.

11. Khashan AS, Henriksen TB, Mortensen PB, McNamee R, McCarthy FP, Pedersen MG, et al. The impact of maternal celiac disease on birthweight and preterm birth: a Danish population-based cohort study. Hum Reprod 2010;25:528-34.
12. Ludvigsson JF, Montgomery SM, Ekbom A. Celiac disease and risk of adverse fetal outcome: a population-based cohort study. Gastroenterology 2005;129:454-63.

13. Greco L, Veneziano A, Di Donato L, Zampella C, Pecoraro M, Paladini D, et al. Undiagnosed celiac disease does not appear to be associated with unfavourable outcome of pregnancy. Gut 2004;53:149-51.

14. Pauzner R, Rothman P, Schwartz E, Neumann G, Farfel $\mathrm{Z}$. Acute onset of celiac disease in the puerperium. Am J Gastroenterol 1992;87:1037-9.

15. Malnick SD, Atali M, Lurie Y, Fraser G, Geltner D. Celiac sprue presenting during the puerperium: a report of three cases and a review of the literature. J Clin Gastroenterol 1998;26:164-6.

16. Jennings A, Swart S. An acute presentation of coeliac disease in the puerperium. J Obstet Gynaecol 2007;27:86-7.

17. Ozaslan E, Küçükazman M, Topal F, Akbulut S, Altiparmak E. Celiac disease presenting in the postpartum period. Dig Dis Sci 2007;52:1101-2.

18. Todd GR, Love AH, Sheridan B, Kennedy L. Hyperprolactinaemia and coeliac disease. Lancet 1984;1:574.

19. Terekeci H, Top C. Gebelik ve romatizmal hastalıklar. Turk J Rheumatol 2008;23:143-50.

20. McGuire JL, Lambert RE. Arthropathies associated with endocrine disorders. In: Kelly WN, Harris ED Jr, Ruddy S, Sledge CB, editors. Textbook of rheumatology. Philadelphia: W.B. Saunders; 1993. p. 1527-44. 